\title{
THE EFFECT OF IONIC LIQUIDS WITH (-)-MENTHOL DERIVATIVE CONTAINING A CHLORIDE ANION TO WEED
}

\author{
WPLYW CIECZY JONOWYCH POCHODNYCH MENTOLU ZAWIERAJĄCYCH \\ ANION CHLORKOWY NA CHWASTY
}

\begin{abstract}
Weeds constitute a huge group of undesirable plants, widespread throughout the world. They represent a big problem for most farmers, who implement different methods to fight against them. Thanks to their wide occurrence, weeds however, can be an excellent indicator of the quality of soil and the whole environment where they are present. In this paper, we present the impact of four alkylimidazolium chlorides with a natural terpene component introduced into the soil: $(1 R, 2 S, 5 R)-(-)-$ menthol and alkyl substituents containing $1,4,9$ or 12 carbon atoms, on the growth and development of selected weed species. Compounds with the highest phytotoxic activity towards gallant soldier, white goosefoot and common sorrel were chlorides with methyl and butyl substituents, while compounds with nonyl and dodecyl substituents demonstrated a weak effect on these weeds. Phytotoxicity of the salts tested was largely dependent on the applied concentration of the compound and the genetic make-up of plant species used in the experiment. This was reflected in the inhibition of plants' length and their roots, as well as changes in the content of dry matter and photosynthetic pigments.
\end{abstract}

Keywords: ionic liquids, chlorophyll, dry weight, inhibition of plant growth and roots, phytotoxicity, gallant soldier, white goosefoot, common sorrel

\section{Introduction}

Weeds are defined as all undesirable plants growing in a particular place. Simultaneously, plants which are treated as weeds in one place, in the other place will be cultivated and considered desirable [1]. Among weeds commonly occurring in Poland, throughout Europe, and in other parts of the world, gallant soldier (Galinsoga parviflora Cav.), white goosefoot commonly known as white goosefoot (Cheopodium album L.) and common sorrel (Rumex acetosa L.) can be found. These plants are characterized by a very fast growth and easy adaptation to different conditions. All three species of plants are anemophilous, produce large amounts of seeds which can survive in soil for several years waiting for appropriate growth conditions, while in terms of white goosefoot seeds retain

\footnotetext{
${ }^{1}$ Department of Biochemistry and Ecotoxicology, Faculty of Science and Natural Science, Jan Długosz University, al. Armii Krajowej 13/15, 42-200 Częstochowa, Poland, phone +48 $34 \quad 3614918$, fax +48 3436653 22, email: r.biczak@ajd.czest.pl; b.pawlowska@ajd.czest.pl

${ }^{2}$ Faculty of Chemistry, Wrocław University of Science and Technology, ul. Wybrzeże Wyspiańskiego 27 , 50-370 Wrocław, Poland, phone +48 7132029 75, email: joanna.feder-kubis@pwr.edu.pl

*Corresponding author: r.biczak@ajd.czest.pl
} 
germination ability even up to 30 years. Although these plants are considered weeds in many countries, there are also regions of the world, e.g. Asia, where they are grown and used as food for humans and animals. Green deciduous plants are in fact the cheapest and readily available source of vitamins, minerals and amino acids. Young common sorrel plants are used as an ingredient in salads, while older and mature leaves are used to prepare soups and sauces. White goosefoot seeds are processed into flour and used to produce bread and cakes. They are cooked and mixed with other ingredients to form a kind of porridge, or may be roasted and ground as a so-called oatmeal and used for the preparation of alcoholic beverages. Gallant soldier due to high protein content, can be used as a green fodder. Due to its rich chemical composition, these plants have widely been used in herbal medicine [2-5].

Despite so many possibilities of using at least some part of weeds, in agricultural crops they still constitute a huge problem for farmers because they compete with crops for light, water and nutrients. As a consequence of a very fast growth, weeds can prevail crops, they also cause deterioration in the quality of the crop, delaying harvest, hamper mechanical harvesting and generate additional costs associated with the necessity of purifying the harvest of seeds and their residues. In order to protect crops from weeds, different methods are used. In earlier centuries, these were physical and mechanical methods, while nowadays mainly chemical methods are in use. Among the most important substances used to fight against weeds, derivatives of phenoxyacetic acid (MCPA, 2,4-D and MCPP), benzoic acid (dicamba) or glyphosate are used. However, currently used compounds do not have a neutral effect on human and animal health. In the last century, it has been observed that some species of weeds developed resistance to traditionally used herbicides. Although there are herbicides such as e.g. MCPA, against which we have not observed a phenomenon of weeds' resistance, there is a continuous need to search towards new compounds exhibiting selective or global herbicidal properties, which are also harmless for humans, animals and the whole natural environment in its broadest sense $[1,6,7]$.

A very interesting and promising new class of compounds which exhibit desirable herbicidal properties are herbicidal ionic liquids (HILs). These are third-generation ionic liquids, also called phytopharmaceuticals which exhibit increased biological activity and multifunctional properties. The structure of HILs is characterized by at least one ion with confirmed herbicidal properties. These compounds have a high chemical and thermal stability, are less soluble in water and allow to reduce the dose of preparation per hectare, which significantly increase the safety of these preparations, reduce the risk for the natural environment and is economically justified [8-11].

An interesting group of ionic liquids are also salts with natural terpene component such as $(1 R, 2 S, 5 R)-(-)$-menthol. This group includes ammonium compounds, pyridinium, alkylimidazoline, alkoxymethylimidazoline compounds and symmetrical imidazolium salts with various anions [12]. Among the chiral ionic liquids (CILs), a particularly interesting group are 3-alkyl-1-[(1R,2S,5R)-(-)-menthoxymethyl]imidazolium chlorides. It has been observed that the presence of natural alcohol, terpene $(1 R, 2 S, 5 R)-(-)$-menthol in these compounds affects their biological properties. Bacteriostatic and fungistatic activity as well as bactericidal and fungicidal properties of the chiral ionic liquids described, have been studied previously [13]. Moreover, imidazolium salts exhibit excellent antistatic properties regardless of the alkyl chain length [12].

In the present study, an attempt was made to evaluate the effect of four 3-alkyl-1-[(1R,2S,5R)-(-)-menthoxymethyl]imidazolium chlorides introduced into the soil, 
on the growth and development of popular weed species in Poland: gallant soldier, white goosefoot and common sorrel. The objective of this study was to find new chemical compounds exhibiting selective or global herbicidal properties. Simultaneously, an attempt was made to determine the effect of the chiral salts on popular and widespread plants, aimed at protecting the natural environment against the harmful effect of ILs, which are becoming more and more popular chemical compounds, already used in different branches of industry.

\section{Materials and methods}

\section{Chemicals}

Ionic liquids used in this study were synthesized in the Department of Chemical Engineering of the Faculty of Chemistry of the Wrocław University of Technology. Briefly, a flask containing a vigorously stirred mixture of dry hexane and freshly distilled appropriate 1-alkylimidazole (1-methylimidazole, 1-butylimidazole 1-nonylimidazole or 1-dodecylimidazole) was added dropwise with chloromethyl $(1 R, 2 S, 5 R)-(-)$-menthyl ether. The resulting reaction mixture was stirred for $90 \mathrm{~min}$ at room temperature. After 180 minutes, the phases were separated. The crude product was washed with dry hexane. The volatiles were removed overnight at $60^{\circ} \mathrm{C}$ and under reduced pressure $(0.3 \mathrm{~mm} \mathrm{Hg})$. In order to obtain analytically pure salts, 3-alkyl-1-[(1R,2S,5R-(-)-menthoxymethyl] imidazolium chlorides with the alkyl substituent: $\mathrm{CH}_{3}, \mathrm{C}_{4} \mathrm{H}_{9}, \mathrm{C}_{9} \mathrm{H}_{19}$ and $\mathrm{C}_{12} \mathrm{H}_{25}$ (Fig. 1) were further dried under pressure $0.3 \mathrm{~mm} \mathrm{Hg}$ (vacuum).

Detailed description of the preparation and physicochemical properties of the obtained chiral ionic liquids are described in the previous publication [12]. The synthesized salts were characterized by ${ }^{1} \mathrm{H}$ NMR and ${ }^{13} \mathrm{C}$ NMR. The obtained results were consistent with the results presented earlier [12].

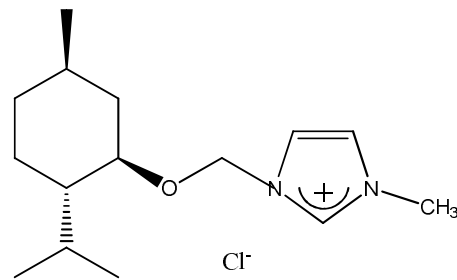

$1-[(1 R, 2 S, 5 R)-(-)$-menthoxymethyl $]-3-$ methylmidazolium chloride $\left[\mathrm{C}_{1}-\mathrm{Im}\right][\mathrm{Cl}]$

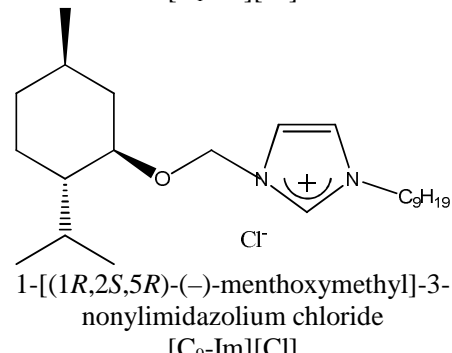

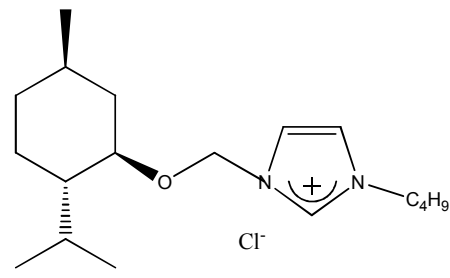

3-butyl-1-[(1R,2S,5R)-(-)-menthoxymethyl]imidazolium chloride $\left[\mathrm{C}_{4}-\mathrm{Im}\right][\mathrm{Cl}]$

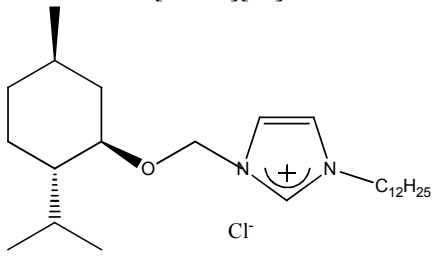

3-dodecyl-1-[(1R,2S,5R)-(-)menthoxymethyl]imidazolium chloride $\left[\mathrm{C}_{12}-\mathrm{Im}\right][\mathrm{Cl}]$

Fig. 1. Structures, full names and abbreviations of analysed chiral ionic liquids 


\section{Examination of soil-applied 3-alkyl-1-[(1R,2S,5R-(-)-menthoxymethyl]imidazolium chlorides toxicity}

A pot experiment to determine the potential herbicidal properties of 3-alkyl-1-[(1R, $2 S$, $5 R$-(-)-menthoxymethyl]imidazolium chlorides was carried out in the vegetation hall of the Department of Biochemistry and Ecotoxicology at the Jan Długosz University in Czestochowa. Equal amount (referred to as wt) of the seeds of examined weeds (Rumex acetosa L., Chenopodium album L., Galinsoga parviflora Cav.), seed in pots containing $250 \mathrm{~g}$ of soil. The soil used in the experiment was light loam, $\mathrm{pH}=6.0$, organic carbon content $0.9 \%$ and dissolved matter containing of approx. $10 \%$. The study concerning the determination of soil-applied salts effect on selected weed species was carried out for 28 days. During the entire experiment, a constant temperature of $20 \pm 2{ }^{\circ} \mathrm{C}$, constant moisture content of the substrate $(70 \%$ water capacity in the field) was maintained, and constant illumination $160 \mu \mathrm{mol} \mathrm{m} \mathrm{m}^{-2} \mathrm{~s}^{-1}$ in the system $16 \mathrm{~h} /$ day and $8 \mathrm{~h} / \mathrm{night}$. The test compounds were added to the soil in aqueous solutions (introduction), and the weeds were seeded on such prepared substrate. Alkiloimidazolium chloride were used in a concentration of 100,500 and $1000 \mathrm{mg} \cdot \mathrm{kg}^{-1}$ of soil dry weight (d.w.).

Visual evaluation of examined weed species growth inhibition, damages or withering was used as an indicator of analyzed compounds phytotoxicity, which was documented in the form of digital images presented in this paper. Also the content of chlorophylls and carotenoids in the examined plants and the inhibition of plants and their roots growth were evaluated. The effective concentrations $\left(E C_{50}\right)$ were estimated by the non-linear regression using GraphPad Prism software (GraphPad Software, Inc., La Jolla, CA, USA).

\section{Determination of pigments content and dry weight}

The content of photosynthetic pigments was determine in according with the method described by Oren et al. [14]. $0.2 \mathrm{~g}$ of fresh leaves were homogenized with $20 \mathrm{~cm}^{3}$ of $80 \%$ acetone. Extraction was carried out for 24 hours in the dark. After this time, the extract was centrifuged and the supernatant obtained was used to determine the content of chlorophylls. To determine the content of chlorophyll $a$, chlorophyll $b$ and carotenoids, absorbance at $470 \mathrm{~nm}, 647 \mathrm{~nm}$ and $664 \mathrm{~nm}$ was measured. The obtained content of photosynthetic pigments is expressed in $\mathrm{mg} \cdot \mathrm{g}^{-1}$ of fresh leaf weight (f.w.).

The dry weight level was determined using an oven-dry method [15], drying about $1 \mathrm{~g}$ fresh weight of the plant at a temperature of $105^{\circ} \mathrm{C}$ to a constant weight obtaining. The dry weight content was provided in $\mathrm{g} \cdot \mathrm{g}^{-1} \mathrm{f}$.w.

\section{Statistical analysis}

Data from three measurements $(n=3)$ were analyzed using one-way ANOVA. The LSD values were calculated using the Tukey test. Differences on the level of $p<0.05$ were considered significant. The mean standard deviations, which are given in the tables and plotted on the charts, were also determined. All results were expressed as mean \pm standard deviation.

\section{Results and discussion}

Results on the growth and development of weeds obtained in this experiment and concerning the interaction of selected chiral alkylimidazoline chlorides with substituents with different number of carbon atoms in the chain, introduced into the soil, can 
demonstrate that the substances tested can be considered compounds characterized by selective herbicidal activity. Toxicity, which was observed towards plants was affected to the greatest extent by the length of the alkyl substituent in CILs, compound concentration and the genetic make-up of species and plants' varieties used in the experiment.

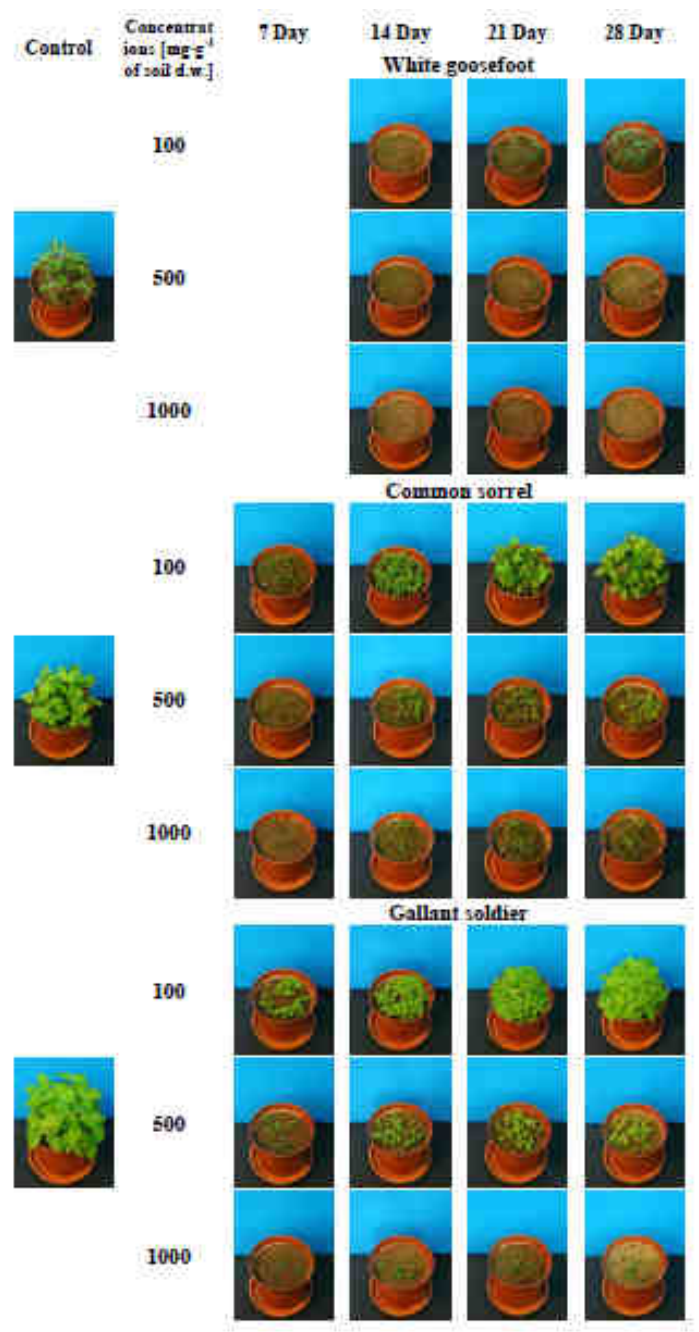

Fig. 2. The reaction weeds in the soil application of $1-[(1 R, 2 S, 5 R)-(-)$-menthoxymethyl $]-3-$ methylimidazolium chloride $\left[\mathrm{C}_{1}-\mathrm{Im}\right][\mathrm{Cl}]$

Compounds exhibiting the strongest herbicidal properties were $1-[(1 R, 2 S, 5 R)-(-)$ menthoxymethyl]-3-methylimidazolium and 3-butyl-1-[(1R,2S,5R)-(-)-menthoxymethyl]imidazolium chloride chlorides. The plant which was the most susceptible to salt $\left[\mathrm{C}_{1}-\mathrm{Im}\right][\mathrm{Cl}]$ was white goosefoot. At the lowest concentration used, only minor changes in the appearance of this plant were observed, the use of higher concentrations resulted in 
a major reduction of plant growth while at the concentration of $1000 \mathrm{mg} \cdot \mathrm{kg}^{-1}$ of soil d.w., we observed germination of single seeds solely and white goosefoot plants dried very quickly. Moreover, for gallant soldier plants and common sorrel, there were no major changes after application of this compound at the concentration of $100 \mathrm{mg} \cdot \mathrm{kg}^{-1}$ of soil d.w., whereas the concentration of 500 and $1000 \mathrm{mg} \cdot \mathrm{kg}^{-1}$ of soil d.w. resulted in a huge reduction of growth and development of plants. Inhibition of growth was the greater, the higher the concentration of the compound used. Moreover, gallant soldier plants growing in the soil with the addition of [C1] were more yellow compared to those from the controls (Fig. 2).

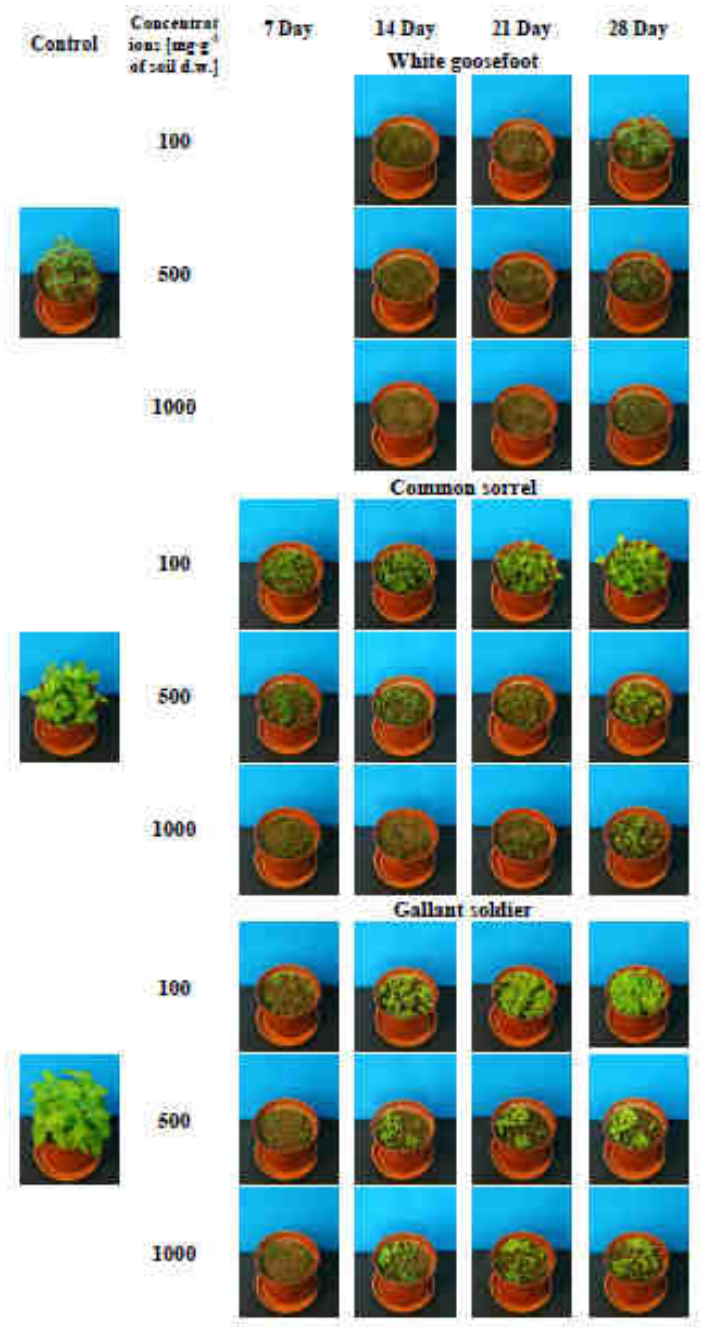

Fig. 3. The reaction weeds in the soil application of 3-butyl-1-[(1R,2S,5R)-(-)-menthoxymethyl]imidazolium chloride $\left[\mathrm{C}_{4}-\mathrm{Im}\right][\mathrm{Cl}]$ 
Similar changes as in the case of salts with methyl substituent, were also observed after application of 3-butyl-1-[(1R,2S,5R)-(-)-menthoxy-methyl]imidazolium chloride. $\left[\mathrm{C}_{4}-\mathrm{IM}\right][\mathrm{Cl}]$ at low concentrations did not lead to major changes in the appearance of the weeds tested, while the use of higher concentrations resulted in a relevant growth inhibition in these plants (Fig. 3).

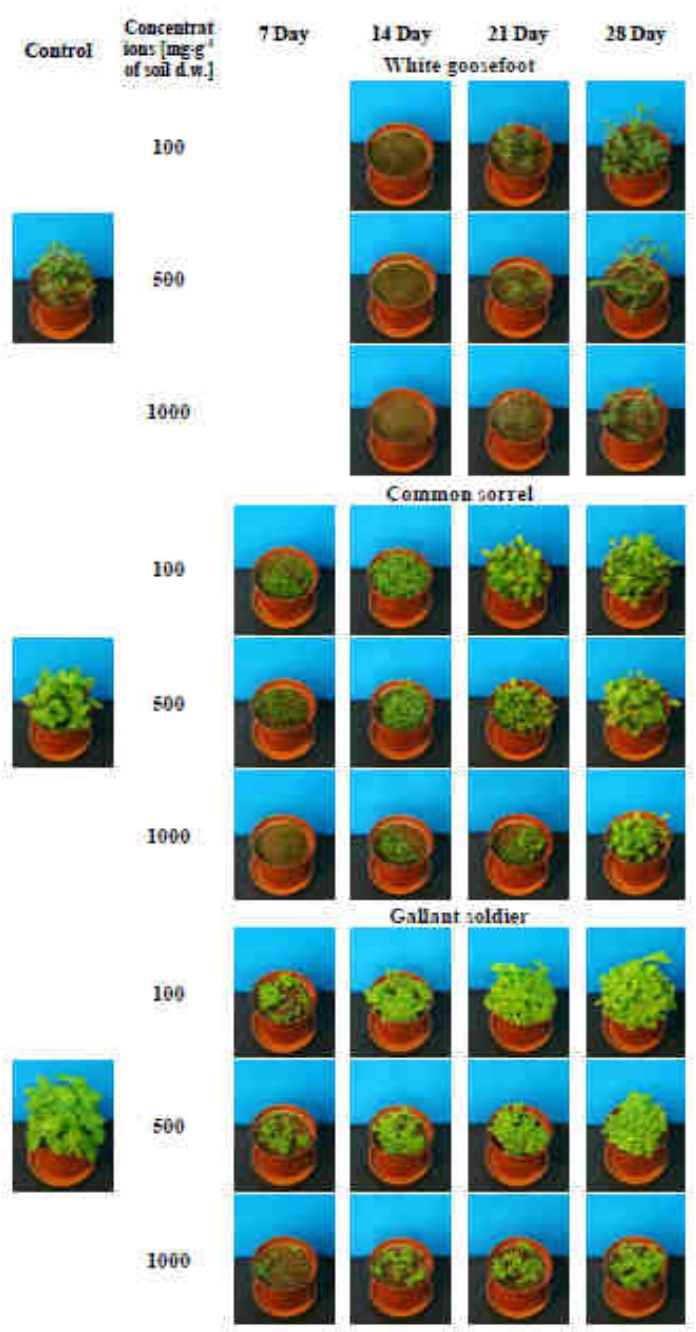

Fig. 4. The reaction weeds in the soil application of $1-[(1 R, 2 S, 5 R)-(-)$-menthoxymethyl]-3nonylimidazolium chloride $\left[\mathrm{C}_{9}-\mathrm{Im}\right][\mathrm{Cl}]$

Minor changes in the appearance of the plants were observed after application of quaternary imidazolium chlorides with nonyl $\left[\mathrm{C}_{9}-\mathrm{Im}\right][\mathrm{Cl}]$ and dodecyl $\left[\mathrm{C}_{12}-\mathrm{IM}\right][\mathrm{Cl}]$ substituents, while also in terms of these CILs, concentration of $100 \mathrm{mg} \cdot \mathrm{kg}^{-1}$ of soil d.w., did not lead to major changes in the appearance of weeds. The use of higher concentrations 
of salts resulted in a particular reduction of plant growth. Plant which was the most susceptible to the activity of both compounds was white goosefoot. Gallant soldier and common sorrel appeared to be the most resistant to the presence of $\left[\mathrm{C}_{9}-\mathrm{Im}\right][\mathrm{Cl}]$ and $\left[\mathrm{C}_{12}-\mathrm{Im}\right][\mathrm{Cl}]$ in the soil, respectively (Figs. 4 and 5).

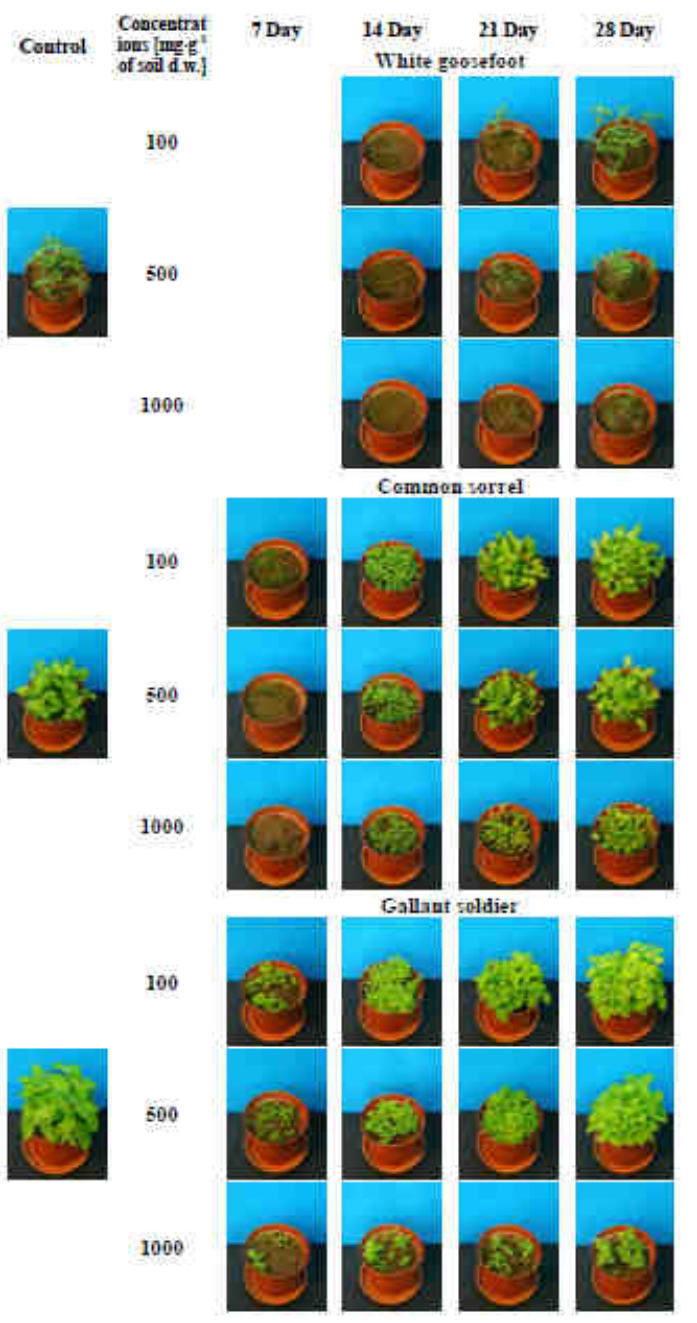

Fig. 5. The reaction weeds in the soil application of 3-dodecyl-1-[(1R,2S,5R)-(-)menthoxymethyl]imidazolium chloride $\left[\mathrm{C}_{12}\right.$-Im-Men $][\mathrm{Cl}]$

Observations based on the appearance of the plants were reflected in the percentage growth inhibition calculated for plants and the values of $E C_{50}$ determined. The calculated $E C_{50}$ values also demonstrate, that CILs with the shortest alkyl chains (containing 1 and 4 carbon atoms) were more toxic compounds for the weeds under study. The salt which induced the least inhibition of plant growth was chloride $\left[\mathrm{C}_{12}-\mathrm{Im}\right][\mathrm{Cl}]$ (Table 1). 
Inhibition of growth plant gallant soldier, common sorrel and white goosefoot exposed to

$\left[\mathrm{C}_{1}-\mathrm{Im}\right][\mathrm{Cl}],\left[\mathrm{C}_{4}-\mathrm{Im}\right][\mathrm{Cl}],\left[\mathrm{C}_{9}-\mathrm{Im}\right][\mathrm{Cl}]$ and $\left[\mathrm{C}_{12}-\mathrm{Im}\right][\mathrm{Cl}]$ in soil (mean $\pm \mathrm{SD}, n=3$ )

\begin{tabular}{|c|c|c|c|c|c|c|}
\hline $\begin{array}{l}\text { Concentration } \\
\text { of QAS }\left[\mathrm{mg} \cdot \mathrm{kg}^{-1}\right. \\
\text { of soil d.w.] }\end{array}$ & $\begin{array}{c}\text { White } \\
\text { goosefoot }\end{array}$ & $\begin{array}{c}E C_{50}\left[\mathrm{mg} \cdot \mathrm{kg}^{-1}\right. \\
\text { of soil d.w. }]\end{array}$ & $\begin{array}{c}\text { Common } \\
\text { sorrel }\end{array}$ & $\begin{array}{c}E C_{50}\left[\mathrm{mg} \cdot \mathrm{kg}^{-1}\right. \\
\text { of soil d.w. }]\end{array}$ & $\begin{array}{l}\text { Gallant } \\
\text { soldier }\end{array}$ & $\begin{array}{c}E C_{50}\left[\mathrm{mg} \cdot \mathrm{kg}^{-1}\right. \\
\text { of soil d.w. }\end{array}$ \\
\hline$\left[\mathrm{C}_{1}\right.$-IM] $(100)$ & $28 \pm 7$ & \multirow{3}{*}{$351 \pm 1$} & $20 \pm 8$ & \multirow{3}{*}{$237 \pm 1$} & $40 \pm 6$ & \multirow{3}{*}{$138 \pm 1$} \\
\hline$\left[\mathrm{C}_{1}\right.$-IM] $(500)$ & $57 \pm 6$ & & $74 \pm 5$ & & $84 \pm 6$ & \\
\hline$\left[\mathrm{C}_{1}-\mathrm{IM}\right](1000)$ & $68 \pm 3$ & & $100 \pm 0$ & & $88 \pm 4$ & \\
\hline$\left[\mathrm{C}_{4}-\mathrm{IM}\right](\mathbf{1 0 0})$ & $21 \pm 8$ & \multirow{3}{*}{$474 \pm 1$} & $24 \pm 6$ & \multirow{3}{*}{$288 \pm 1$} & $67 \pm 7$ & \multirow{3}{*}{$25 \pm 2$} \\
\hline$\left[\mathrm{C}_{4}\right.$-IM] (500) & $56 \pm 6$ & & $68 \pm 3$ & & $86 \pm 2$ & \\
\hline$\left[\mathrm{C}_{4}-\mathrm{IM}\right](1000)$ & $61 \pm 5$ & & $74 \pm 7$ & & $86 \pm 2$ & \\
\hline$\left[\mathrm{C}_{9}\right.$-IM] $(100)$ & $-22 \pm 13$ & \multirow{3}{*}{$1051 \pm 3$} & $19 \pm 6$ & \multirow{3}{*}{$1213 \pm 2$} & $33 \pm 11$ & \multirow{3}{*}{$330 \pm 2$} \\
\hline$\left[\mathrm{C}_{9}\right.$-IM] (500) & $-17 \pm 6$ & & $28 \pm 7$ & & $49 \pm 8$ & \\
\hline$\left[\mathrm{C}_{9}\right.$-IM] $(1000)$ & $28 \pm 12$ & & $51 \pm 6$ & & $75 \pm 5$ & \\
\hline$\left[\mathrm{C}_{12}\right.$-IM] $(100)$ & $-22 \pm 15$ & \multirow{3}{*}{$1394 \pm 3$} & $26 \pm 4$ & \multirow{3}{*}{$1243 \pm 1$} & $-5 \pm 14$ & \multirow{3}{*}{$958 \pm 1$} \\
\hline$\left[\mathrm{C}_{12}\right.$-IM] (500) & $23 \pm 7$ & & $37 \pm 7$ & & $-1 \pm 13$ & \\
\hline$\left[\mathrm{C}_{12}\right.$-IM] (1000) & $34 \pm 8$ & & $50 \pm 6$ & & $15 \pm 5$ & \\
\hline
\end{tabular}

Table 2

Inhibition of growth root gallant soldier, common sorrel and white goosefoot exposed to

$\left[\mathrm{C}_{1}-\mathrm{Im}\right][\mathrm{Cl}],\left[\mathrm{C}_{4}-\mathrm{Im}\right][\mathrm{Cl}],\left[\mathrm{C}_{9}-\mathrm{Im}\right][\mathrm{Cl}]$ and $\left[\mathrm{C}_{12}-\mathrm{Im}\right][\mathrm{Cl}]$ in soil (mean $\pm \mathrm{SD}, n=3$ )

\begin{tabular}{|c|c|c|c|c|c|c|}
\hline $\begin{array}{c}\text { Concentration } \\
\text { of QAS }\left[\mathrm{mg} \cdot \mathrm{kg}^{-1}\right. \\
\text { of soil d.w.] }\end{array}$ & $\begin{array}{c}\text { White } \\
\text { goosefoot }\end{array}$ & $\begin{array}{c}E C_{50}\left[\mathrm{mg} \cdot \mathrm{kg}^{-1}\right. \\
\text { of soil d.w. }]\end{array}$ & $\begin{array}{c}\text { Common } \\
\text { sorrel }\end{array}$ & $\begin{array}{c}E C_{50}\left[\mathrm{mg} \cdot \mathrm{kg}^{-1}\right. \\
\text { of soil d.w. }\end{array}$ & $\begin{array}{l}\text { Gallant } \\
\text { soldier }\end{array}$ & $\begin{array}{c}E C_{50}\left[\mathrm{mg} \cdot \mathrm{kg}^{-1}\right. \\
\text { of soil d.w.] }\end{array}$ \\
\hline$\left[\mathrm{C}_{1}\right.$-IM] $(100)$ & $46 \pm 10$ & \multirow{3}{*}{$161 \pm 1$} & $20 \pm 13$ & \multirow{3}{*}{$185 \pm 1$} & $9 \pm 22$ & \multirow{3}{*}{$218 \pm 1$} \\
\hline$\left[\mathrm{C}_{1}\right.$-IM] (500) & $58 \pm 4$ & & $90 \pm 3$ & & $93 \pm 3$ & \\
\hline$\left[\mathrm{C}_{1}-\mathrm{IM}\right](1000)$ & $71 \pm 5$ & & $100 \pm 0$ & & $97 \pm 1$ & \\
\hline$\left[\mathrm{C}_{4}\right.$-IM] $(100)$ & $51 \pm 8$ & \multirow{3}{*}{$91 \pm 1$} & $39 \pm 11$ & \multirow{3}{*}{$136 \pm 1$} & $39 \pm 10$ & \multirow{3}{*}{$130 \pm 1$} \\
\hline$\left[\mathrm{C}_{4}\right.$-IM] (500) & $79 \pm 6$ & & $88 \pm 4$ & & $93 \pm 2$ & \\
\hline$\left[\mathrm{C}_{4}-\mathrm{IM}\right](1000)$ & $91 \pm 5$ & & $91 \pm 3$ & & $93 \pm 1$ & \\
\hline$\left[\mathrm{C}_{9}\right.$-IM] (100) & $7 \pm 7$ & \multirow{3}{*}{$877 \pm 1$} & $0 \pm 10$ & \multirow{3}{*}{$837 \pm 1$} & $-2 \pm 8$ & \multirow{3}{*}{$559 \pm 1$} \\
\hline$\left[\mathrm{C}_{9}\right.$-IM] (500) & $9 \pm 9$ & & $5 \pm 12$ & & $40 \pm 12$ & \\
\hline$\left[\mathrm{C}_{9}\right.$-IM] (1000) & $63 \pm 7$ & & $74 \pm 5$ & & $76 \pm 7$ & \\
\hline$\left[\mathrm{C}_{12}\right.$-IM] $(100)$ & $-10 \pm 17$ & \multirow{3}{*}{$736 \pm 1$} & $16 \pm 9$ & \multirow{3}{*}{$937 \pm 1$} & $15 \pm 9$ & \multirow{3}{*}{$1111 \pm 2$} \\
\hline$\left[\mathrm{C}_{12}-\mathrm{IM}\right](500)$ & $21 \pm 8$ & & $17 \pm 10$ & & $19 \pm 8$ & \\
\hline$\left[\mathrm{C}_{12}\right.$-IM] (1000) & $55 \pm 8$ & & $55 \pm 6$ & & $27 \pm 19$ & \\
\hline
\end{tabular}

Higher values of inhibition in comparison to plant growth, were observed for the length of weeds' roots under study. After application of $\left[\mathrm{C}_{1}-\mathrm{Im}\right][\mathrm{Cl}]$ and $\left[\mathrm{C}_{4}-\mathrm{Im}\right][\mathrm{Cl}]$ compounds at the concentrations of 500 and $1000 \mathrm{mg} \cdot \mathrm{kg}^{-1}$ of soil d.w., inhibition of root growth for white goosefoot and common sorrel was about $90 \%$ compared to the controls. Only in terms of gallant soldier, the values of root growth inhibition were smaller and ranged between 60 and 90\%. Lower, but also statistically significant values of inhibition were observed after application of these compounds at the lowest concentration equal to $100 \mathrm{mg} \cdot \mathrm{kg}^{-1}$ of soil d.w. After introduction of $\left[\mathrm{C}_{9}-\mathrm{Im}\right][\mathrm{Cl}]$ and $\left[\mathrm{C}_{12}-\mathrm{Im}\right][\mathrm{Cl}]$ into the soil, the values of growth inhibition of roots were slightly lower compared to these observed for CILs with shorter chains. However, for the concentration of $1000 \mathrm{mg} \cdot \mathrm{kg}^{-1}$ of soil d.w., also for these compounds, more than $50 \%$ growth inhibition of roots was reported. Solely for common sorrel, after application of $\left[\mathrm{C}_{12}-\mathrm{Im}\right][\mathrm{Cl}]$ at the concentration of $1000 \mathrm{mg} \cdot \mathrm{kg}^{-1}$ of soil d.w., inhibition calculated from the root length was lower and was equal to $27 \%$ in 
relation to the controls. The $E C_{50}$ values calculated based on the inhibition of root length confirmed the above-mentioned observations (Table 2).

As a result of the studies conducted, we also identified the effect of CILs on the dry matter content in gallant soldier, white goosefoot common sorel plants. For weeds growing in the soil with the addition of $\left[\mathrm{C}_{1}-\mathrm{Im}\right][\mathrm{Cl}]$ and $\left[\mathrm{C}_{4}-\mathrm{Im}\right][\mathrm{Cl}]$, an increase in dry weight in relation to the controls was observed even at the lowest concentration $\left(100 \mathrm{mg} \cdot \mathrm{kg}^{-1}\right.$ of soil d.w.). Increased levels of the dry weight of plants was the greater, the higher the concentration of CILs. After introduction of $\left[\mathrm{C}_{9}-\mathrm{Im}\right][\mathrm{Cl}]$ and $\left[\mathrm{C}_{12}-\mathrm{Im}\right][\mathrm{Cl}]$ into the soil, changes in the dry matter content was significantly smaller in comparison to compounds with shorter chains. In this case, lack of linear correlation between the concentration of the compounds and the level of dry matter in weed plants, was observed (Table 3 ).

Table 3

Effect of $\left[\mathrm{C}_{1}-\mathrm{Im}\right][\mathrm{Cl}],\left[\mathrm{C}_{4}-\mathrm{Im}\right][\mathrm{Cl}],\left[\mathrm{C}_{9}-\mathrm{Im}\right][\mathrm{Cl}]$ and $\left[\mathrm{C}_{12}-\mathrm{Im}\right][\mathrm{Cl}]$ in soil on dry weight weeds (mean $\pm \mathrm{SD}, n=3$ )

\begin{tabular}{|c|c|c|c|c|}
\hline \multirow{2}{*}{\multicolumn{2}{|c|}{$\begin{array}{c}\text { Concentration of } \\
\text { QAS }\left[\mathrm{mg} \cdot \mathrm{kg}^{-1} \text { of }\right. \\
\text { soil d.w. }]\end{array}$}} & \multicolumn{3}{|c|}{ Dry weight $\left[g \cdot g^{-1}\right.$ f.w. $]$} \\
\hline & & \multirow{2}{*}{$\begin{array}{c}\text { White goosefoot } \\
0.1072 \pm 0.0024\end{array}$} & \multirow{2}{*}{$\begin{array}{c}\text { Common sorrel } \\
0.1041 \pm 0.0025\end{array}$} & \multirow{2}{*}{$\begin{array}{c}\text { Gallant soldier } \\
0.1357 \pm 0.0038\end{array}$} \\
\hline & $\mathbf{0}$ & & & \\
\hline \multirow[t]{3}{*}{$\mathrm{C}_{1}$-IM] } & 100 & $0.1213 \pm 0.0078$ & $0.1259 \pm 0.0049$ & $0.1539 \pm 0.0072$ \\
\hline & 500 & $0.1732 \pm 0.0101$ & $0.1497 \pm 0.0057$ & $0.2406 \pm 0.0062$ \\
\hline & 1000 & - & - & - \\
\hline \multirow[t]{3}{*}{$\mathrm{C}_{4}$-IM] } & 100 & $0.1008 \pm 0.0073$ & $0.1392 \pm 0.0017$ & $0.1904 \pm 0.0009$ \\
\hline & 500 & $0.1537 \pm 0.0026$ & $0.1591 \pm 0.0043$ & $0.1905 \pm 0.0048$ \\
\hline & 1000 & $0.4297 \pm 0.0089$ & $0.2730 \pm 0.0096$ & $0.2086 \pm 0.0128$ \\
\hline \multirow[t]{3}{*}{$\mathbf{C}_{9}$-IM] } & 100 & $0.1082 \pm 0.0105$ & $0.1176 \pm 0.0001$ & $0.1543 \pm 0.0013$ \\
\hline & 500 & $0.0992 \pm 0.0059$ & $0.1160 \pm 0.0036$ & $0.1284 \pm 0.0031$ \\
\hline & 1000 & $0.1034 \pm 0.0064$ & $0.1142 \pm 0.0027$ & $0.1342 \pm 0.0054$ \\
\hline \multirow[t]{3}{*}[\mathrm{C}_{12}-\mathrm{IM}]{} & 100 & $0.1117 \pm 0.0030$ & $0.1135 \pm 0.0037$ & $0.1515 \pm 0.0171$ \\
\hline & 500 & $0.0974 \pm 0.0009$ & $0.1047 \pm 0.0049$ & $0.1345 \pm 0.0005$ \\
\hline & 1000 & $0.1109 \pm 0.0011$ & $0.1132 \pm 0.0018$ & $0.1208 \pm 0.0021$ \\
\hline \multicolumn{2}{|c|}{$\mathbf{L S D}_{0.05}$} & 0.0034 & 0.0022 & 0.0054 \\
\hline
\end{tabular}

The most important biomarker of oxidative stress in plants induced by different abiotic factors, including the presence of ionic liquids in the environment, is the content of assimilation pigments. In this study, we evaluated the content of all photosynthetic pigments in, common sorrel, gallant soldier and white goosefoot plants growing in the soil with the addition of tested compounds at different concentrations, and in plants growing in the control soil. In all experimental plants, we reported a decrease in the content of chlorophyll $a$ and $b$, total chlorophyll $(a+b)$ and carotenoids under the influence of chlorides tested. Observed decrease in the level of assimilation pigments in weeds was mostly correlated with an increase in the concentration of CILs in the soil. Only in terms of white goosefoot, we observed slight deviation from this principle, because after application of $\left[\mathrm{C}_{1}-\mathrm{Im}\right][\mathrm{Cl}]$ and $\left[\mathrm{C}_{9}-\mathrm{Im}\right][\mathrm{Cl}]$ at a concentration of $100 \mathrm{mg} \cdot \mathrm{kg}^{-1}$ of soil d.w., a slight increase in the content of chlorophyll $a$, chlorophyll $b$, carotenoids and total chlorophyll, was reported. The study conducted also confirmed changes in the ratio of chlorophyll $a$ to chlorophyll $b$ and the total chlorophyll to carotenoids ratio, possibly indicating the occurrence of oxidative stress in the experimental plants treated with CILs (Table 4). 
Content of assimilation pigments in common sorrel, gallant soldier and white goosefoot leaves exposed to $\left[\mathrm{C}_{1}-\mathrm{Im}\right][\mathrm{Cl}],\left[\mathrm{C}_{4}-\mathrm{Im}\right][\mathrm{Cl}],\left[\mathrm{C}_{9}-\mathrm{Im}\right][\mathrm{Cl}]$ and $\left[\mathrm{C}_{12}-\mathrm{Im}\right][\mathrm{Cl}]($ mean $\pm \mathrm{SD}, n=3)$

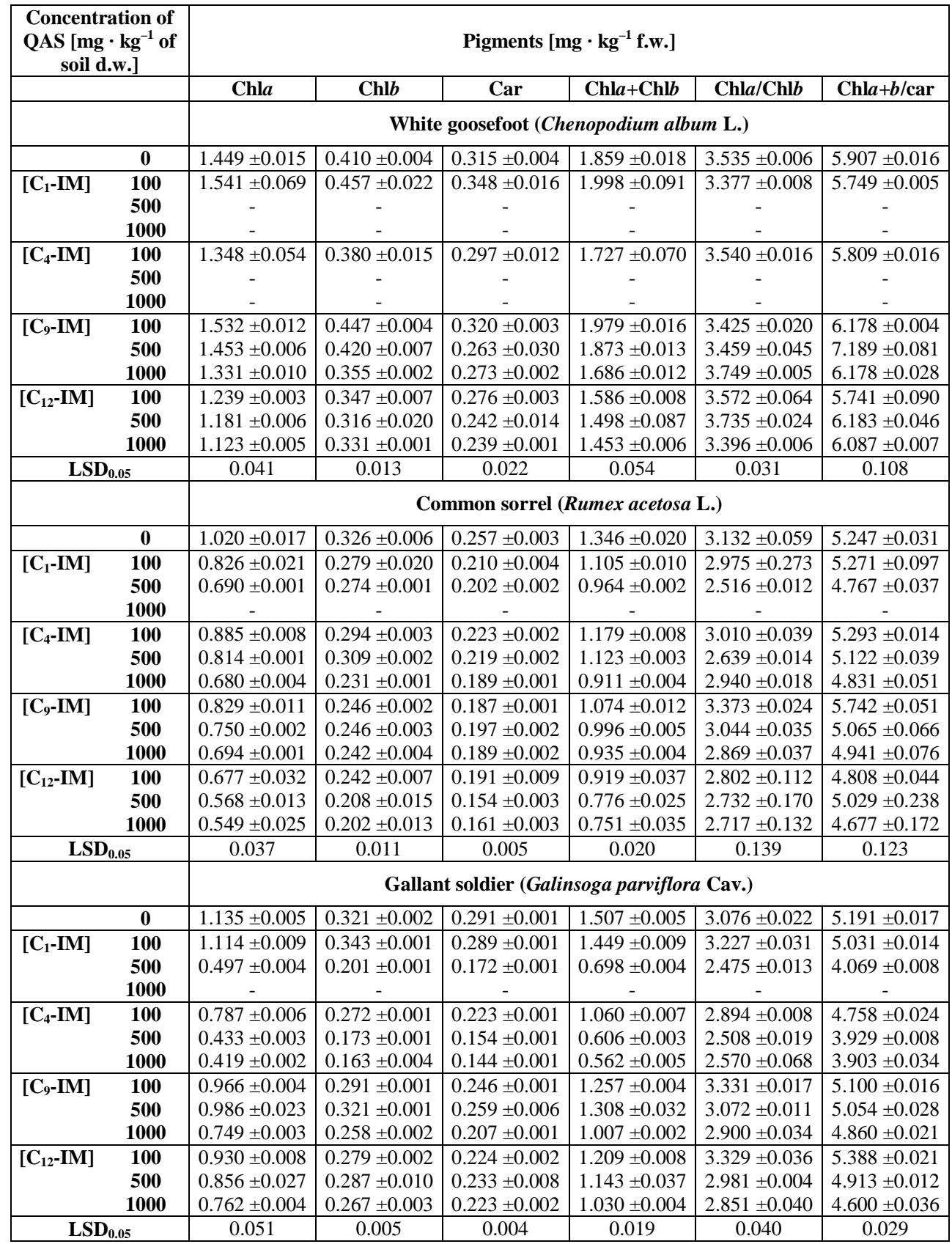


The results obtained in this experiment conclusively prove that alkylimidazoline chlorides with $(1 R, 2 S, 5 R$-(-)-menthol component exhibit potential herbicidal properties and their activity depend on the length of the alkyl substituent, compound concentration and plant species. The toxic effect of the tested ionic liquids may be related to the fact that the compounds were added to the soil, and therefore to the environment where the plants grow and from where they absorb water and nutrients. Moreover, plants can also absorb harmful chemical substances from the soil together with nutrients.

The presence of toxic compounds in the soil can inhibit the growth of plants and their roots, as well as may interfere with physiological development of the whole plant. For highly toxic compounds, even complete inhibition of seeds' germination is possible [16-19]. In this study, the compounds exhibiting the strongest herbicidal properties were $\left[\mathrm{C}_{1}-\mathrm{Im}\right][\mathrm{Cl}]$ and $\left[\mathrm{C}_{4}-\mathrm{Im}\right][\mathrm{Cl}]$. A similar phytotoxic activity of salt with the same cation structure however with tetrafluoroborate anion, applied in the form of spray on white goosefoot, gallant soldier and common sorrel leaves, was reported by Biczak et al. [20]. The authors undoubtedly prove that the greatest phytotoxicity is exhibited by chiral ionic liquids containing substituents with the lowest number of carbon atoms (from 1 up to 6). Further elongation of the substituent's chain does not increase toxicity of the compound, but on the contrary, CILs with long chains in the substituent do not exhibit toxicity any longer in relation to higher plants. Similar conclusions were also made by Matzke et al. [21] who determined the toxicity of imidazolium ionic liquids with 2, 4 and 8 carbon atoms substituents for wheat and cress and found that ionic salts with the longest substituent did not show high phytotoxicity. Stepnowski et al. [22] in his studies demonstrated, that ionic liquids with long alkyl chain substituents easily undergo sorption onto soil colloids and thus are less available to plants, while the compounds with shorter alkyl chains in the substituent can easily be transmitted in the soil and are more accessible to plants. However, there are papers [23], which show that the toxicity of ionic liquids - imidazolium bromide for barley seedlings, can increase along with elongation of the substituent from 4 to 10 carbon atoms. Different conclusions between studies, can be associated with the type of soil used in the experiments and may especially result from the content of soil colloids, which may bind ionic liquids making them less available to plants and consequently non-toxic [21, 24, 25].

Toxic effects of ILs in the present study was also dependent to a large extent on the concentration of the salt used. These observations are confirmed in the literature $[19,20$, $23,26]$. In these papers, almost a totally linear correlation was demonstrated between the concentration of the compound used and its toxicity in plants. Close relationship between the phytotoxicity of ionic liquids and the concentration used, was also confirmed by the studies conducted by Wang et al. [27] and Liu et al. [28], in which it was confirmed that high concentrations of tetrafluoroborate and hexafluorophosphates exhibited an inhibition effect on the growth and development of wheat seedlings. The relationship between the toxicity and concentration of the compound used, is particularly evident at high ILs concentrations, while minor addition of these substances may cause stimulation of plant growth and development.

Assessing the dry matter content in plant leaves as an indicator of the influence of chemical compounds on plant productivity, we observed increased value of this parameter compared to the controls. This indicator was highly correlated with the concentration of the compound, i.e. the higher the concentration used, the greater the increase in dry matter content in the leaves of plants. Increase in the dry matter content in plants which stay in contact with chemical compounds is also reported by Biczak et al. $[18,20]$. In contrast to 
the results of the cited studies, results obtained by Liu et al. [29], indicated a relevant decrease in the dry matter content in leaves of this plant when describing the reaction of bean to the introduction of 1-butyl-3-methylimidazolium chloride into the soil. Differences between the results of studies are likely caused by the fact that different plant species may react differently to the presence of chemical compounds in the soil.

The content of assimilation pigments is considered the best biomarker reflecting changes in plant cells under the influence of the presence of harmful substances in the environment. In the studies conducted by Ma et al. [30], Zhang et al. [31], Liu et al. [32], and Wang et al. [27] on algae, duckweed, bean leaves, leek and wheat seedlings, almost a totally linear relationship between the decrease in the content of assimilation pigments in these plants and the increase in the concentration of chemical substances in the soil, was reported. Moreover, these authors also demonstrate that the presence of harmful chemical substances leads to oxidative stress, which results in the overproduction of reactive oxygen species (ROS) which damage membranes of the chloroplasts. As a consequence, we observe a disruption in the production of chlorophyll, which in turn may lead to premature aging of the plant. In our study, we reported a decrease in the content of chlorophyll $a$, chlorophyll $b$, carotenoids, and total chlorophyll in common sorrel, gallant soldier and white goosefoot plants, which undeniably proves the disturbance in the photosynthesis process. Stupnica-Rodzynkiewicz et al. [33] when evaluating the content of chlorophylls in cockspur grass, green foxtail, white goosefoot and common sorrel under the influence of eight phenolic acids, and Yao et al. [34] in white goosefoot under the influence of $\mathrm{NaCl}$ and $\mathrm{KCl}$, also observed almost linear correlation between an increase in the concentration of the compound and a decrease in the content of assimilation pigments in plants. Similarly as in the studies conducted by the cited researchers, in our experiment we also obtained almost linear correlations between an increase in the concentration of a compound in the soil and a decrease in the content of assimilation pigments in plants. A slight increase in the content of assimilation pigments in white goosefoot in relation to the controls when using the lowest concentration of the compound $\left(100 \mathrm{mg} \cdot \mathrm{kg}^{-1}\right.$ of soil d.w.) can be associated with an increase in the content of carotenoids in these plants, which evidences about increased defense of the plants against stress. Carotenoids are one of the basic elements of the PSI and PSII protection systems against the harmful effect of reactive oxygen species [35-37].

\section{Conclusions}

The results described in this experiment allow to conclude that the chiral ionic liquids: 3-aklyl-1-[(1R,2S,5R)-(-)-menthoxymethyl]imidazolium chlorides with methyl, butyl, nonyl and dodecyl substituents exhibit selective herbicidal properties. Activity of the tested compounds was largely dependent on the length of the alkyl substituent, concentration of CILs and plant species. The compounds exhibiting the strongest phytotoxicity were quaternary imidazolium salts with fewer carbon atoms (1 and 4) in the alkyl chain. Moreover, almost linear correlation between the effects of ionic liquids on the growth and development of plants and the applied concentration of these compounds, was observed. In the case of the highest concentration used, all CILs showed herbicidal effect against weeds used in the experiment. This was reflected in the growth inhibition of plants and their roots, calculated $E C_{50}$ values, and also in the content of the dry weight and assimilation pigments in white goosefoot, coomon sorrel and gallant soldier leaves. 
The study results on the effect of alkylimidazolium ionic liquids on the growth and development of common weed species, can also be used to assess the risk of the above-mentioned CILs for different elements of the natural environment. The data obtained can also be used to design new compounds with potential selective or global herbicide properties, which would also exhibit as low toxicity as possible towards broader environmental context.

\section{Acknowledgements}

The work was financed by a statutory activity subsidy from the Polish Ministry of Science and Higher Education for The Faculty of Mathematics and Natural Sciences of Jan Długosz University in Czestochowa and the Faculty of Chemistry of Wroclaw University of Science and Technology.

\section{References}

[1] Duke SO. Herbicide - Resistant Crops: Agricultural, Environmental, Economic, Regulatory, and Technical Aspects, Boca Raton: Lewis Publisher; 1996.

[2] Choudhary SP, Sharma DK. Internat J Pharmacogn. 2014;1(9):545-552. DOI: 10.13040/IJPSR.0975-8232.IJP.1(9).545-52.

[3] Tuazon-Nartea J, Savage G. Food Nutr Sci. 2013;4:838-843. DOI: 10.4236/fns.2013.48109.

[4] Poonia A, Upadhayay A. J Food Sci Technol. 2015;52(7):3977-3985. DOI: 10.1007/s13197-014-1553-x.

[5] Bazylko A, Boruc K, Borzym J, Kiss AK. Phytochem. Lett. 2015;11:394-398. DOI: 10.1016/j.phytol.2014.11.005.

[6] Niemczak M, Giszter R, Czerniak K, Marcinkowska K, Walkiewicz F. RSC Adv. 2015;5:15487-15493. DOI: $10.1039 / \mathrm{c} 4 \mathrm{ra} 16151 \mathrm{c}$.

[7] Kimura O, Tsukagoshi K, Endo T. Toxicol Lett. 2009;189:102-109. DOI:10.1016/j.toxlet.2009.05.006.

[8] Pernak J, Niemczak M, Materna K, Żelechowski K, Marcinkowska K, Praczyk T. RSC Adv. 2016. DOI: 10.1039/C5RA23997D.

[9] Polit JT, Praczyk T, Pernak J, Sobiech Ł, Jakubiak E, Skrzypczak G. Acta Physiol Plant. 2014;36:699-711. DOI: 10.1007/s11738-013-1448-x.

[10] Cojocaru OA, Shamshina JL, Gurau G, Syguda A, Praczyk T, Pernak J, et al. Green Chem. 2013;15:2110-2120. DOI: 10.1039/C3GC37143C.

[11] Pernak J, Niemczak M, Materna K, Marcinkowska K, Praczyk T. Tetrahedron. 2013;69:4665-4669. DOI: 10.1016/j.tet.2013.03.097.

[12] Pernak J, Feder-Kubis J, Cieniecka-Rosłonkiewicz A, Fischmeister C, Grifin ST, Rogers RD. New J Chem. 2007;31:879-892. DOI: 10.1039/b616215k.

[13] Feder-Kubis J, Bryjak J. Acta Biochim Pol. 2013;60:741-745. www.actabp.pl.

[14] Oren R, Werk KS, Buchmann N, Zimmermann R. Can J For Res. 1993;23:1187-1195. DOI: $10.1139 / \mathrm{x} 93-150$.

[15] Rychter P, Kot M, Bajer K, Rogacz D, Šišková A, Kapuśniak J. Carbohydr Polym. 2016;137:127-138. DOI: 10.1016/j.carbpol.2015.10.0510.

[16] Chapman N, Miller AJ, Lindsey K, Whalley WR. Trends Plant Sci. 2012;17:701-710. DOI: 10.1016/j.tplants.2012.08.001.

[17] Peric B, Sierra J, Martí E, Cruañas R, Garau MA. Chemosphere. 2014;108:418-425. DOI: 10.1016/j.chemosphere.2014.02.043.

[18] Biczak R. J Hazard Mater. 2016;304:173-185. DOI: 10.1016/j.jhazmat.2015.10.055.

[19] Pawłowska B, Biczak R. Chemosphere. 2016;149:24-33. DOI: 10.1016/j.chemosphere.2016.01.072.

[20] Biczak R, Pawłowska B, Feder-Kubis J. Environ Sci Pollut Res. 2015;22:11740-11754. DOI: $10.1007 / \mathrm{s} 11356-015-4327-8$.

[21] Matzke M, Stolte S, Böschen A, Filser J. Green Chem. 2008;10:784-792. DOI: 10.1039/b802350f.

[22] Stepnowski P, Mrozik W, Nichthauser J. Environ Sci Technol. 2007;41:511-516. DOI: 10.1021/es062014w.

[23] Cvjetko Bubalo M, Hanousek K, Radošević K, Srček VG, Jakovljević T, Radojčić Redovniković I. Ecotox Environ Saf. 2014;101:116-123. DOI: 10.1016/j.ecoenv.2013.12.022.

[24] Studzińska S, Kowalkowski T, Buszewski B. J Hazard Mater. 2009;186:1542-1547. DOI: 10.1016/j.jhazmat.2009.03.029. 
[25] Mrozik W, Jungnickel C, Paszkiewicz M, Stepnowski P. Water Air Soil Pollut. 2013;224:1759-1765. DOI: 10.1007/s11270-013-1759-y.

[26] Liu H, Zhang S, Hu X, Chen C. Environ Pollut. 2013;181:242-249. DOI: 10.1016/j.envpol.2013.06.007.

[27] Wang L-S, Wang L, Wang L, Wang G, Li Z-H, Wang J-J. Environ Toxicol. 2009;24:296-303. DOI: 10.1002/tox.20435.

[28] Liu T, Zhu L, Xie H, Wang J, Wang J, Sun F, et al. Environ Sci Pollut Res. 2014;21:3936-3945. DOI: 10.1007/s11356-013-2348-8.

[29] Liu H, Zhang S, Zhang X, Chen C. J Hazard Mater. 2015;286:440-448. DOI: 10.1016/j.hazmat.2015.01.008.

[30] Ma J-M, Cai L-L, Zhang B-J, Hu L-W, Li X-Y, Wang J-J. Ecotoxicol Environ Saf. 2010;73:1465-1469. DOI: 10.1016/j.ecoenv.2009.10.004.

[31] Zhang B, Li X, Chen D, Wang J. Protoplasma. 2013;250:103-110. DOI: 10.1007/s00709-012-0379-5.

[32] Liu T, Zhu L, Wang J, Wang J, Xie H. J Hazard Mater. 2015;285:27-36. DOI: 10.1016/j.hazmat.2014.11.028.

[33] Stupnicka-Rodzynkiewicz E, Dabkowska T, Stoklosa A, Hura T, Dubert F, Lepiarczyk A. J Plant Dis Prot. 2006; Special issue XX:479-486.

[34] Yao S, Chen S, Xu D, Lan H. Plant Growth Regul. 2010;60:115-125. DOI: 10.1007/s10725-009-9426-4.

[35] Arias-Baldrich C, Bosch N, Begines D, Feria AB, Monreal JA, García-Mauriño S. J Plant Physiol. 2015;183:121-129. DOI: 10.1016/j.jplph.2015.05.016.

[36] Gengmao Z, Yu H, Xing S, Shihui L, Quanmei S, Changhai W. Ind Crops Prod. 2015;64:175-181. DOI: 10.1016/j.indcrop.2014.10.058.

[37] Biczak R, Telesiński A, Pawłowska B. Plant Physiol Biochem. 2016;107:248-256. DOI: 10.1016/j.plaphy.2016.05.016. 